\title{
Pre-Merger and Post-Merger Operating Performance of SBI
}

\author{
Farman Ali, Anshul Sharma
}

\begin{abstract}
In today's business world the corporate and PSUs have practiced of major restructuring through merger and acquisition strategies. This is well acknowledged fact Mergers and Acquisitions are being considered as an admired strategy for augmentation. This research paper is based on how the merger of SBI associates into its parents company affects the financial performance on consolidation basis. In this article we analyzed the financial position before merger and after merger of SBI and find out an increase in the profitability by few parameters in short run while it gives the hike in performance as well as in efficiency for long term basis because of low operating cost. It has been observed that after the merger, bad loan pile up, suddenly the profit of the bank come down, during this period when the entire economy of India was facing the pressure of demonetization and GST regime in India while SBI was thinking to be indexed in top 50 banks of the world. This research article also reveals the fact and figures how mergers \& acquisitions have consequences and effects on financial position of the bank performance considering five years from the very beginning of pre and post observation period. In this study t-test is used to evaluate all financial parameters before and after merger of five $S B I$ associates into $S B I$ and it is found that for short period of time, after merger the $S B I$ did not perform well but after two years it has not only increased its profitability but also increase the efficiency by minimizing the operating cost.
\end{abstract}

Index Terms: Key Ratio Analysis, Merger, Pre \& Post merger value of SBI

\section{INTRODUCTION}

Merger of SBI associates into SBI is only the way to assist these banking units it will not only support to the profitability of their associates but also a golden chance to SBI to increase its market share in untapped market of India. From the last two decades the whole Indian Banking is being consolidated to bring in the payback of mergers \& acquisition. The foremost and supreme responsibility of Banks is to accelerate economic upswing in the country and provides finance for investments. Now a day's banking industry has gone through a transfigure stage in terms of rules and regulation with the insistence of globalization. These modifications in the policies have overblown this sector's structure and strategic decision making. In this paradigm shift a lot of different corporate level strategy has been adopted by banking companies to be much more cost effective and to upsurge ahead globally. Mergers and acquisitions are one of the prominent strategies which undertake the consolidation of banking companies and resulted as one of the unrivalled commercial game plan for financial institutions. To make stronger the banking industry the most prevailing practice

Revised Manuscript Received on August 25, 2019

FarmanAli, Uttaranchal University, Dehradun, farman.disha@gmail.com

Dr. Anshul Sharma, Uttaranchal University, Dehradun embrace by banks is merger. The government of India has been introduced to a great extent of reforms in the Indian banking sector for strengthening this industry but there are few successful mergers and acquisitions relatively. These reforms are supporting it to grow multiple. The first ever and the most flourishing and profitable pattern of merger were New Bank of India merged into the Punjab National Bank (PNB).It was the first merger among the nationalized (Public Sector Banks) banks. After this successful consolidation banking there have been a bunch of mergers in Indian banking system which resulted that Mergers are favorable for Indian banking industry. The biggest merger in the history of banking world is the five associates of SBI \& one more Bharatiya Mahila Bank merged into SBI bank. These 'associates' banks are 'State Bank of Bikaner and Jaipur' (SBBJ), 'State Bank of Hyderabad' (SBH), 'State Bank of Mysore'(SBM), 'State Bank of Patiala'(SBP), 'State Bank of Travancore' (SBT) and Bharatiya Mahila Bank. The merger was take place on 1st April 2017 with a vision of nourishing the associated sick units of SBI.

\section{LITERATURE REVIEW}

Some attempts have been done by research scholar in the field of merger \& acquisition which are analyzed and shaped up in tabular form.

Singh \& Kumar (1994), Ravi S.\& Rao studied the restructuring of non-profitable companies by the way of merger and acquisition with the wealthy companies is the most effective way of healing their sickness. Vashisht (1987) analyzed the operating performance of government sector banks. It has a positive result over the six parameters after the merger, like branch growth, deposit ratio, credit policy, priority sector advances, Loan \& advances, and net profit margin throughout 1971-83.

Cornett \&Tehranian (1992) studied the financial position of largest bank merger between 1982 and 1987. The findings of their study concluded greater performance for merged banks because of the improvements in capacity to attract loans and deposits through the public.

Atma (1996) generalized the growth of Indian banking sector has been remarkable after the banking sector reforms so the present banking structure is the end result of the processes of growth, amalgamation, merger \&acquisition reform.

This has given the positive response.

Gelli (1998) examined the privileged position of capital backing of the banks were essential, only mergers can accomplish it. 


\section{Pre-Merger and Post-Merger Operating Performance of SBI}

Kumar\&Kishore.(2003)there were no predetermined closing stages to improve the levels of efficiency and profitability.Chanda (2005) studied that the after the merger and acquisition, market prices level of the government undertaking banks was quite impressive.

In addition, it could be state that bank mergers could not always be an invocation for their customers. Sometime it swells the possibilities for monopolistic competition.

Dash Ashutosh. (2005) found that the today's mergers are mainly aggravated by the firms which have sound financial condition with above industry average performances and this tendency continues to carry on overtime for the sick units. Mohan (2006) studied Indian banking Industry has been saturated because of their expansion while it has a lack of scaling up as per the global standard so merger \& acquisition is only the way to sort out this problem.

Dimikris \&Ketemina(2006), Santos(2006), Nazir \& Alam(2010),Mohamad Akbar et al (2012)find out and concludes the practical efficiency and productivity have been increased but there is turn down in the net worth by the way of merger, acquisition and takeover.

Healy, Ghosh, Kruse, Weston \& Mansigka,Vijay \& Saxena. Altunbas \& Mantravadi \& Reddy. (2007) concluded the operating performance of merging firms improved considerably after the merger and acquisitions because of low operating cost, the reason behind they stated after having the efficiency in the operation.

Muhammad(2010) criticized the M\&A and how these strategies are not successful to revive the financial performance of bank.Antony Akhil (2011), Pramod \& Reddy, Tambi (2005), Bhide et. al (2002), Anup Agraval (1999), Beena P L (2000), Leepsa et al (2009), Saplev V(2000) There is a noteworthy improvement in the productivity of merged firm. It has a correlation with the financial performance before and after merger. The merged private and public both bank achieved sound financial position by way of maximizing their wealth.

Vardhan.P.(2001),Kumar(2009),Surjit(2002),Vanitha\&Selv an.(2007)studied Merger does not have any impact on the financial position of the companies whether it is public sector or private sector financial Institutions.

Nedunchezhin and Premalatha (2011), Sathye (2003), Ataullah et al (2006) concluded that those Public sector banks which are supported by central government achieved more efficiency and more profitability as compared to Private sector banks during the post merger period.

Mantravadi \& Reddy (2007) observed that the mergers of same groups of companies do not have any positive effect on the financial position of the consolidated one; there has been disgrace operational performance and ROI after the merger of identical sector's companies.

Khan (2011) has concluded that merged banks can easily attain their efficiency and profitability through merger \& acquisitions. These institutions passes the benefits to the all stakeholders in the form of high rate of return to the shareholders and better services to their customers by generating higher net profits margins along with more market share.

Gerard T. O \& Michael S. P(2005 (2011),studied an increase in the profit as well as return on equity after the merger in banking industry and state the problem how acquiring banks interest are reasonable and cost effective determinants of merged banks anomalous stock return performance.
Sai and Sultana (2013) It has been concluded that Net earnings, EBIT, ROCE, ROE and Debt/ Equity ratio there was no any transforming and significant change in these ratios before merger and after mergers these ratios remain as it is. There was only one parameter which has significant difference i.e. Gross Profit Margin.

Monika (2014) she concluded that the mergers \& acquisitions expressed value mixed motives to attract the investors by way of corporate level strategy and use behavioral theories to understand the philosophy behind the decisions to adopt a form of consolidation. Vulanovic (2017-18) found that the merger doesn't have positive impact on the capital adequacy financial and operating performance of the company. The companies which are occupied the merger reported zero or negative outcome in the financial performance. Singh \& Bansal (2017-18) and Shijaku (2017) found the key financial ratios are essential to appraise the productivity and efficiency of the bank In financial world the decisions of investment and financing can be made on behalf of these parameters.

Table I: Explore the findings of previous research scholars before and after merger of different financial institutions as well as companies.

\begin{tabular}{|c|c|c|c|}
\hline Authors & Impact & Authors & Impact \\
\hline Singh \& Kumar (1994), Ravi & Positive & Muhammad (2010) & Negative \\
\hline $\begin{array}{l}\text { Shankar..e tao } \\
\text { Vashisht (1987) }\end{array}$ & Positive & $\begin{array}{l}\text { Antony Akhil (2011), Pramod \& Reddy, } \\
\text { Tambi (2005), Bhide et. al (2002) }\end{array}$ & Positive \\
\hline Cornett \& Tehranian (1992) & Strongly positive & $\begin{array}{l}\text { Vardhan Pawaskar (2001), Kumar (2009), } \\
\text { Suritit (2002) }\end{array}$ & Does not affect. \\
\hline Atma (1996) & Positive & $\begin{array}{l}\text { Nedunchezhin and Premalatha (2011), } \\
\text { Sathve (2003), Ataullah et al (2006 }\end{array}$ & Positive \\
\hline Gelli (1998) & Positive & Mantravadi \& Reddy (2007) & Negative \\
\hline Kumar \& Kishore. (2003) & Does not affect & Khan (2011) & Positive \\
\hline Chanda (2005) & Positive & Gerard T O \& Michael S P(2005 (2011), & Positive \\
\hline Dash Ashutosh. (2005) & Positive & Sai and Sultana (2013) & Does not affect \\
\hline Mohan (2006) & Positive & Monika (2014) & Negative \\
\hline $\begin{array}{l}\text { Dimikris \& Ketemina (2006), } \\
\text { Santos(2006) }\end{array}$ & Positive & Vulanovic (2017-18) & Negative \\
\hline $\begin{array}{l}\text { Healy, Ghosh, Kruse, Weston \& } \\
\text { Mansigka }\end{array}$ & Positive & $\begin{array}{l}\text { Singh \& Bansal (2017-18) and Shijaku } \\
(2017)\end{array}$ & Positive \\
\hline
\end{tabular}

\section{OBJECTIVES OF THE STUDY}

1.To weigh up the effects of merger on the financial performance of the SBI by analyzing pre-merger and post-merger ratio of financial parameters.

2. To identify the operating efficiency of the Bank by analyzing per employee and per branch ratio.

\section{SIGNIFICANCE OF THE STUDY}

This analysis of financial performance of SBI is based on pre and post-merger for ten years. How does the profitability of the bank and the information reflect the movement in the share price of the bank?

\section{SOURCES OF DATA}

The research is based on Secondary Sources of data which includes the Annual Reports of the SBI; RBI Database; research publications \&Business news papers etc.

\section{HYPOTHESIS}

H0 $=$ Mergers of SBI associates does not have significant difference in the financial performance of SBI

H1= Mergers of SBI associates have a significant difference in the financial performance of SBI. 


\section{DATA ANALYSIS TOOL}

The arithmetic, statistical and financial ratios analysis and tabulation techniques are used for the analysis of data. For hypothesis testing, $t$-vale. $p$-value, standard deviation, and mean are calculated with the financial data of SBI. The financial performance on the basis of different parameters of the bank before and after the mergers has been statistically compared at 5\% level of significance.

$\mathbf{P}$ value and $\mathbf{t}$ value are used to test the hypothesis. These values are the evidence against the Null hypothesis.

\section{METHODOLOGY}

This study is an endeavor to scan the knock of merger and acquisition of banking segment in India. Although the data of two different periods have been taken to evaluate and examine the performance of SBI profitability after merging entities. The methodology is based on past observations and records which represents the complete research work found in the different state of affairs.

A. Testing of level of significance:

Table II disclose the "mean values and $t$ value" of pre and post-merger of Basic EPS (89.63 and 138.058), and mean of Book Value (547.44 and 971.66) .This change in mean value stipulate there is an elevation in EPS\& Book value after merger. Meanwhile, the mean value of dividend/share (14.6 and 28.083), mean value of operating revenue/share (793.918 and 1214.29), mean value of Net Profit/share (85.662 and 133.226) are increased in post merger period respectively and $\mathrm{P}$ Value in all cases of per share ratios is less than 0.05 so the hypothesis of significance has been accepted.

Table-II: Key Financial Ratios (Per share ratio)

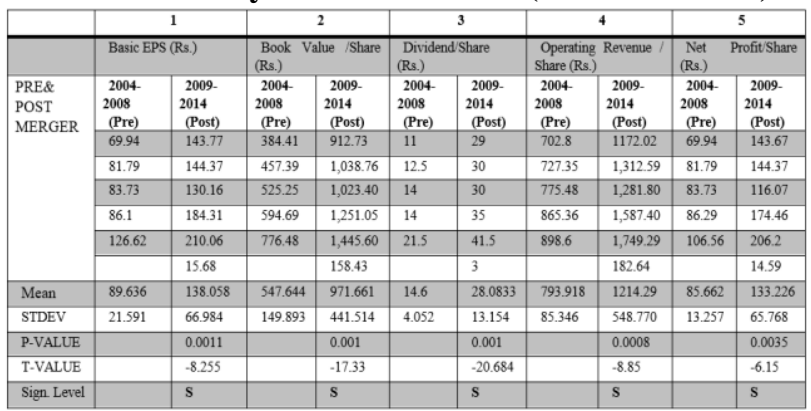

S-Significant if $P \leq 0.05, t \geq 1.96$ (Significance level=.05)

Table-III: Per Employee Ratios

\begin{tabular}{|c|c|c|c|c|c|c|}
\hline & \multicolumn{2}{|c|}{6} & \multicolumn{2}{|c|}{7} & \multicolumn{2}{|c|}{8} \\
\hline & $\begin{array}{l}\text { Interest Inco } \\
\text { (Rs.) }\end{array}$ & 1e/ Employee & Net Profit Em & loyee (Rs.) & Business/ Empl & yee (Rs.) \\
\hline \multirow{7}{*}{$\begin{array}{l}\text { PRE } \quad \& \\
\text { POST } \\
\text { MERGER }\end{array}$} & $\begin{array}{l}\begin{array}{l}2004-2008 \\
\text { (Pre) }\end{array} \\
\end{array}$ & $\begin{array}{l}\begin{array}{l}2009-2014 \\
\text { (Post) }\end{array} \\
\end{array}$ & $\begin{array}{l}\begin{array}{l}2004-2008 \\
\text { (Pre) }\end{array} \\
\end{array}$ & $\begin{array}{l}\begin{array}{l}2009-2014 \\
\text { (Post) }\end{array} \\
\end{array}$ & $\begin{array}{l}\text { 2004-2008 } \\
\text { (Pre) }\end{array}$ & $\begin{array}{l}\begin{array}{l}2009-2014 \\
\text { (Post) }\end{array} \\
\end{array}$ \\
\hline & $1,786,545.20$ & $3,613,923.16$ & $177,792.59$ & $443,001.64$ & $23,406,739.17$ & $62,893,336.88$ \\
\hline & $1,862,658.97$ & $4,160,491.97$ & $209,450.28$ & $457,618.51$ & $28,057,596.25$ & $72,297,238.83$ \\
\hline & $2,053,249.96$ & $3,651,068.43$ & $221,692.56$ & $330,608.20$ & $32,537,711.44$ & $75,836,787.78$ \\
\hline & $2,456,680.64$ & $4,943,426.72$ & $244,962.31$ & $543,309.55$ & $42,075,556.52$ & $88,695,813.20$ \\
\hline & $3,166,411.08$ & $5,241,313.86$ & $375,498.71$ & $617,837.58$ & $53,734,446.54$ & $98,484,254.10$ \\
\hline & & $6,119,627.30$ & & $488,812.02$ & & $116,882,048.03$ \\
\hline Mean & $2,265,109.17$ & $4,621,641.91$ & $245,879.29$ & $480,197.92$ & $35,962,409.98$ & $85,848,246.47$ \\
\hline STDEV & 566771.2772 & 990117.9975 & 76403.37736 & 97234.18524 & 12094165.47 & 19706147.02 \\
\hline P-VALUE & & 0.00020 & & 0.0019 & & 0.0001 \\
\hline T-VALUE & & -12.92 & & -7.17 & & -37.03 \\
\hline Sign. Level & & $\mathrm{s}$ & & $\mathrm{s}$ & & $\mathrm{s}$ \\
\hline
\end{tabular}

S-Significant if $P \leq 0.05, t \geq 1.96$ (Significance level=.05)

\section{B. Testing of level of significance:}

Table III releases the "mean value" of pre and post-merger of Income of interest/ Employee (2265109.17 and 4621641.91)
Net Profit/ Employee (245879.29 and 480197.92) Business/ Employee (35962409.98 and 85848246.47) which were increased in the post - merger period respectively. The impact of merger is positively correlated with the per employee ratio. Since the all P-Values of these ratios are less than 0.05 it shows the impact of the performance over the per employee ratios is highly significant hence the hypothesis of significance is accepted because it has a correlation with the post merger of SBI.

C. Testing of level of significance: Table IV represents the "mean value and t value" of pre and post-merger of Interest Income/Branch (45863456.27 and 71695013.5) Net Profit Branch 4959546.982and 7501125.5) Business Branch (722464872.8 and 1330221305) which all are increased in the post - merger period respectively.

The effects of merger are highly correlated with the efficiency of SBI before and after merger.

Hence the P-Values of these ratios are $(0.0003,0.0008$ and 0.001 respectively) less than 0.05 means merger influenced the performance over Per Branch ratios, which is significantly different hence the hypothesis of significance is accepted after the rejection of Null hypothesis because it has a correlation with the post merger of SBI.

Table IV: Per Branch Ratio

\begin{tabular}{|c|c|c|c|c|c|c|}
\hline & \multicolumn{2}{|c|}{9} & \multicolumn{2}{|c|}{10} & \multicolumn{2}{|c|}{11} \\
\hline & Interest Income & Branch (Rs.) & Net Profit $\mathrm{Br}$ & ches (Rs.) & Business/Branch & s(Rs.) \\
\hline \multirow{7}{*}{$\begin{array}{l}\text { PRE\& } \\
\text { POST } \\
\text { MERGER }\end{array}$} & $\begin{array}{l}\begin{array}{l}\text { 2004-2008 } \\
\text { (Pre) }\end{array} \\
\end{array}$ & $\begin{array}{l}\begin{array}{l}2009-2014 \\
\text { (Post) }\end{array} \\
\end{array}$ & $\begin{array}{l}\text { 2004-2008 } \\
(\mathrm{Pre})\end{array}$ & $\begin{array}{l}2009-2014 \\
\text { (Post) }\end{array}$ & $\begin{array}{l}\begin{array}{l}\text { 2004-2008 } \\
\text { (Pre) }\end{array} \\
\end{array}$ & $\begin{array}{l}\begin{array}{l}2009-2014 \\
\text { (Post) }\end{array} \\
\end{array}$ \\
\hline & $40,677,942.48$ & $64,479,403.99$ & $4,048,168.92$ & $7,904,009.10$ & $532,949,287.58$ & $1,122,139,210.66$ \\
\hline & $41,809,126.04$ & $65,939,419.37$ & $4,701,307.78$ & $7,252,771.80$ & $629,779,040.41$ & $1,145,835,151.21$ \\
\hline & $44,136,769.55$ & $59,420,618.92$ & $4,765,514.87$ & $5,380,601.33$ & $699,432,362.28$ & $1,234,232,925.24$ \\
\hline & $47,441,573.96$ & $74,647,129.22$ & $4,730,528.44$ & $8,204,126.56$ & $812,531,590.83$ & $1,339,331,641.49$ \\
\hline & $55,251,869.33$ & $79,760,764.56$ & $6,552,214.90$ & $9,402,069.66$ & $937,632,083.06$ & $1,498,704,257.70$ \\
\hline & & $85,922,744.91$ & & $6,863,174.55$ & & $1,641,084,645.54$ \\
\hline Mean & 45863456.27 & 71695013.5 & 4959546.982 & 7501125.5 & 722464872.8 & 1330221305 \\
\hline STDEV & 5851097.101 & 10119805.48 & 938614.2055 & 1359073.075 & 157675504.7 & 205725886 \\
\hline P-VALUE & & 0.00033 & & 0.00898 & & 0.001 \\
\hline T-VALUE & & -11.39 & & -4.75 & & -41.35 \\
\hline Sign. Level & & $\mathrm{s}$ & & $\mathrm{s}$ & & $S$ \\
\hline
\end{tabular}

S-Significant if $P \leq 0.05, t \geq 1.96$ (Significance level=.05)

D. Testing of level of significance: Table $V$ represents a significant changes in the "mean values \& $t$ value" of pre and post-merger for Net Profit Margin (10.76\% and 10.50\%), mean value of Operating Profit Margin (11.68\% and $-0.5 \%)$, mean value of Return on assets $(0.89 \%$ and $0.79 \%)$, mean value of Return on Net worth (16.04\% and $13.061 \%)$, mean value of net interest margin (4.03 and 3.021), mean value of cost to income (36.79\% and $36.071 \%$ ) respectively. This performs a minute change in the financial parameters during the post- merger period except the net interest margin.Net Interest Margin has the more significant value $(\mathrm{P}=0.00047)$ in compare to all parameters. Net profit margin, operating profit margin, return on assets, return on equity and cost to income have higher P-value while we compare with the (0.05) level of significance So it can be concluded only net interest income margin is affected by merger and other parameter accept the no significant hypothesis. 


\section{Pre-Merger and Post-Merger Operating Performance of SBI}

Table V: Key Performance Ratios

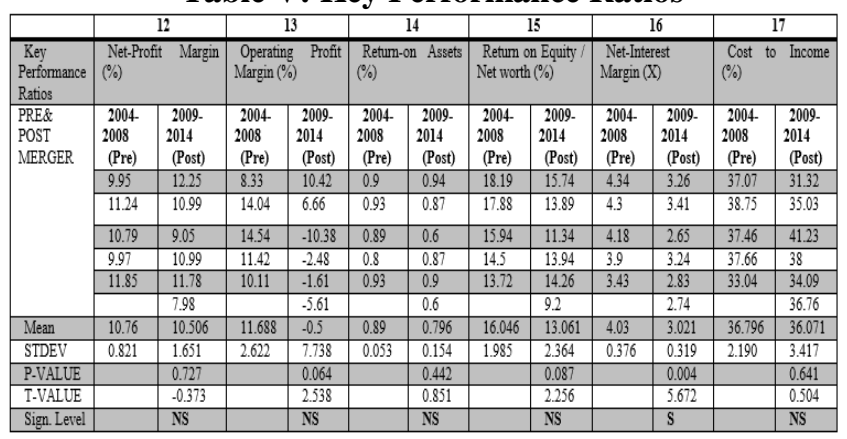

Table VI: Key Performance Ratios

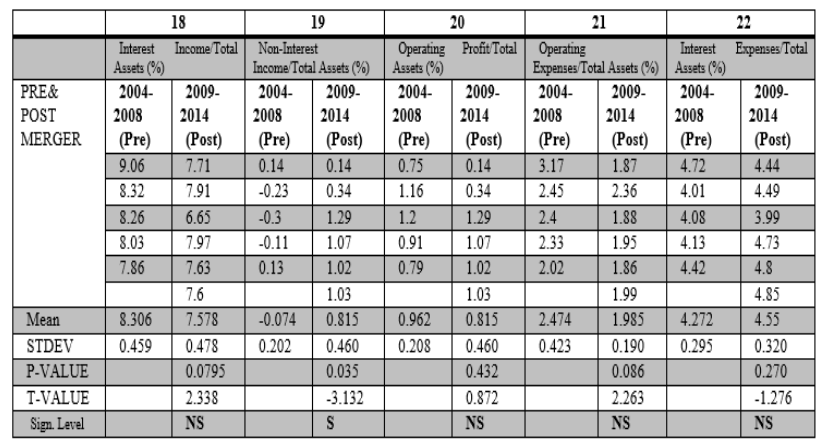

S-Significant if $P \leq 0.05, t \geq 1.96$ (Significance level=.05)

E. Testing of level of significance: Table VI calculated the mean of pre and post-merger for Interest Income/Total Assets $(8.306 \%$ and $7.578 \%)$, mean of Non-Interest Income/Total Assets (- $-0.074 \%$ and $-0.815 \%)$, mean of Operating Profit/Total Assets $(0.962 \%$ and $0.815 \%)$, mean value of Operating Expenses/Total Assets (\%) (2.474\% and 1.985\%), mean value of Interest Expenses/Total Assets (4.272 and 4.55), while P values of pre and post-merger of SBI are $0.0795,0.351,0.4366,0.086$ and 0.270 respectively(Interest Income/Total Assets , Non-Interest Income/Total Assets (Operating Profit/Total Assets, Operating Expenses/Total Assets, Interest Expenses/Total Assets) Hence the only value of non interest income has the significant difference after the merger means increasing in non-interest income because of the transaction charge, bank fees ,draft fees generated more income in compare to the previous years so in this case the null hypothesis is rejected while in all other parameters it is accepted.

Table VII: Valuation Ratios

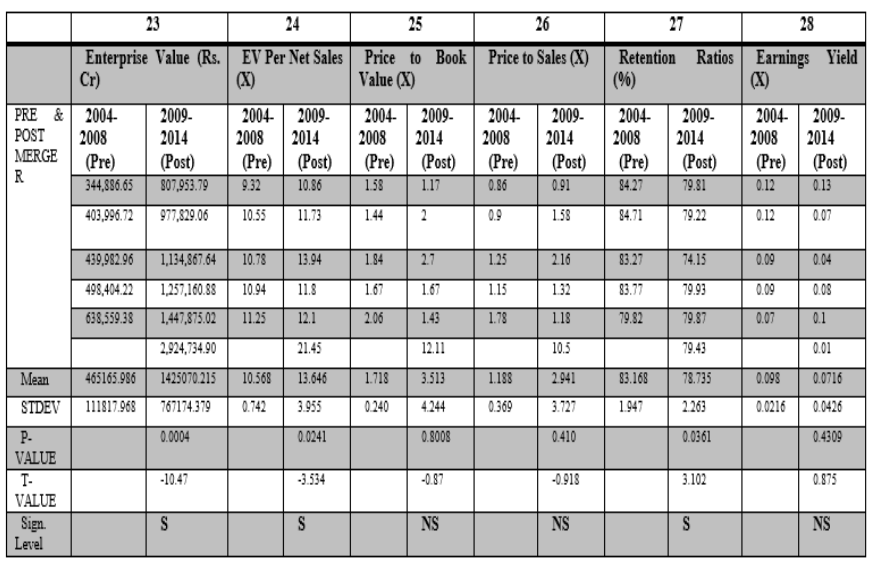

S-Significant if $P \leq 0.05, t \geq 1.96$ (Significance level=.05)
F. Testing of level of significance: Above analysis (see table VII) let out mean value \& $\mathrm{P}$ values of pre and post-merger of Enterprise Value, EV/ Net Sales, Retention Ratios are highly significant which are $(0.0004,0.0241$ and 0.036$)$ less than 0.05 of significant level that's why null hypothesis is rejected while Price to Book Value, Price to sales and Earnings yield are having no significant with the pre merger and post merger because these parameters have higher $\mathrm{P}$ value in compare to hypothesis level. The conclusion of above analysis is that post merger the market value of the SBI has been increased but the decreasing retention ratio affected the earnings of the bank.

Table VIII: Key Financial Ratios (Per Share Ratio) 2004-2008 \& 2015-2019

\begin{tabular}{|c|c|c|c|c|c|c|c|c|c|c|}
\hline & \multicolumn{2}{|c|}{ l } & \multicolumn{2}{|c|}{2} & \multicolumn{2}{|c|}{3} & \multicolumn{2}{|r|}{4} & \multicolumn{2}{|c|}{5} \\
\hline $\begin{array}{l}\text { Per Share } \\
\text { Ratios }\end{array}$ & \multicolumn{2}{|c|}{ Basic EPS (Rs.) } & \multicolumn{2}{|c|}{$\begin{array}{l}\text { Book-Value [ncl. Reval } \\
\text { Reserve] Share (Rs.) }\end{array}$} & \multicolumn{2}{|c|}{$\begin{array}{l}\text { Dividend Per Share } \\
\text { (Rs.) }\end{array}$} & \multicolumn{2}{|c|}{$\begin{array}{l}\text { Operating Revenue Per } \\
\text { Share (Rs.) }\end{array}$} & \multicolumn{2}{|c|}{$\begin{array}{l}\text { Net Profit Per Share } \\
\text { (Rs.) }\end{array}$} \\
\hline \multirow{6}{*}{$\begin{array}{c}\text { PRE\&POS } \\
\text { TMERGER }\end{array}$} & $\begin{array}{l}2004 \\
2008 \text { (Pre) }\end{array}$ & \begin{tabular}{|l}
2015. \\
2019(Post)
\end{tabular} & $\begin{array}{c}2004 \\
2008 \text { (Pre) }\end{array}$ & \begin{tabular}{|l}
2015 - \\
2019(Post)
\end{tabular} & $\begin{array}{l}2004 \\
2008 \text { (Pre) }\end{array}$ & \begin{tabular}{|l}
$2015-$ \\
2019(Post)
\end{tabular} & $\begin{array}{l}2004 \\
2008 \text { (Pre) }\end{array}$ & \begin{tabular}{|l|}
$2015-$ \\
2019(Post)
\end{tabular} & \begin{tabular}{|l|}
2004 \\
2008 (Pre)
\end{tabular} & \begin{tabular}{|l}
2015. \\
2019(Post)
\end{tabular} \\
\hline & 69.94 & 17.55 & 384.41 & 172.04 & 11 & 3.5 & 702.8 & 204.13 & 69.94 & 17.55 \\
\hline & 81.79 & 12.98 & 457.39 & 185.85 & 12.5 & 2.6 & 727.35 & 211.26 & \begin{tabular}{|l|}
81.79 \\
\end{tabular} & 12.82 \\
\hline & 83.73 & 13.43 & 525.25 & 236.14 & 14 & 2.6 & 775.48 & 220.13 & 83.73 & 13.15 \\
\hline & 86.1 & .7 .67 & 594.69 & 245.53 & 14 & 0 & 866.36 & 247.07 & 86.29 & .7 .34 \\
\hline & 126.62 & 0.97 & 77648 & 247.53 & 21.5 & 0 & 898.6 & 272.13 & 10656 & 0.97 \\
\hline Mean & 89.636 & 7.452 & 547.644 & 217.418 & 14.6 & \begin{tabular}{|l|}
1.74 \\
\end{tabular} & 793.918 & 230.944 & 85.662 & 7.43 \\
\hline STDEV & 21.591 & 10.475 & 149.893 & 35.718 & 4.0527 & 1.630 & 85.346 & \begin{tabular}{|l|}
28.194 \\
\end{tabular} & \begin{tabular}{|l|}
13.257 \\
\end{tabular} & 10.296 \\
\hline P.VALUE & & 0.0029 & & 0.0036 & & 0.0058 & & 0.0001 & & 0.0011 \\
\hline T-VALUE & & 6.46 & & 6.06 & & 5.35 & & 21 & & 8.252 \\
\hline Sign. Level & & S & & $\mathrm{S}$ & & $\mathrm{S}$ & & $\mathrm{s}$ & & S \\
\hline
\end{tabular}

S-Significant if $P \leq 0.05, t \geq 1.96$ (Significance level=.05)

G. Testing of level of significance: Table VIII disclose the mean values $\mathrm{t}$ values \& $\mathrm{P}$ values of pre and post-merger of "Basic EPS" (89.63 and 7.452), and mean of "Book Value" (547.44 and 217.418).It is clear by the table that there is downfall in per share ratios the after merger. Meanwhile, mean value of "Dividend per share" (14.6 and 1.74) has been decreased same as mean value of operating revenue/share (793.918 and 230.944), mean value of Net Profit/share (85.662 and 7.43) are decreased in post merger period respectively and $P$ Value in all cases of per share ratios is less than 0.05 so the hypothesis of significance is accepted. It is concluded that per share ratios of SBI has been decreased after merger.

Table IX: Per Employee Ratios

\begin{tabular}{|c|c|c|c|c|c|c|}
\hline & \multicolumn{2}{|c|}{6} & \multicolumn{2}{|c|}{7} & \multicolumn{2}{|c|}{8} \\
\hline & \multicolumn{2}{|c|}{$\begin{array}{l}\text { Interest Income/ Employee } \\
\text { (Rs.) }\end{array}$} & \multicolumn{2}{|c|}{ Net Profit Employee (Rs.) } & \multicolumn{2}{|c|}{ Business/ Employee (Rs.) } \\
\hline \multirow[t]{6}{*}{$\begin{array}{l}\text { PRE\&POST } \\
\text { MERGER }\end{array}$} & \begin{tabular}{|l}
$2004-$ \\
2008 (Pre)
\end{tabular} & \begin{tabular}{|l|}
$2015-$ \\
2019(Post)
\end{tabular} & \begin{tabular}{|l|}
$2004-$ \\
2008(Pre)
\end{tabular} & \begin{tabular}{|c|}
$2015-$ \\
2019(Post)
\end{tabular} & \begin{tabular}{|l}
$2004-$ \\
$2008($ Pre)
\end{tabular} & $\begin{array}{l}\begin{array}{l}2015- \\
\text { 2019(Post) }\end{array} \\
\end{array}$ \\
\hline & $1,786,545.20$ & $7,146,806.58$ & $177,792.59$ & $614,410.75$ & $23,406,739.17$ & $134,911,208.97$ \\
\hline & $1,862,658.97$ & $7,894,439.54$ & $209,450.28$ & $478,997.86$ & $28,057,596.25$ & $153,770,974.81$ \\
\hline & $2,053,249.96$ & $8,375,280.48$ & $221,692.56$ & $500,274.50$ & $32,537,711.44$ & $172,538,127.46$ \\
\hline & $2,456,680.64$ & $8,350,949.88$ & $244,962.31$ & $-247,971.10$ & $42,075,556.52$ & $175,776,620.83$ \\
\hline & $3,166,411.08$ & 0.00 & $375,498.71$ & 0.00 & $53,734,446.54$ & 0.00 \\
\hline Mean & 2265109.17 & 6353495.296 & 245879.29 & 269142.402 & 35962409.98 & 127399386.4 \\
\hline STDEV & 566771.2772 & 3586369.842 & 76403.37736 & 372999.8655 & 12094165.47 & 73075910.13 \\
\hline P-VALUE & & 0.088046527 & & 0.908468676 & & 0.066908803 \\
\hline T-VALUE & & -2.25 & & -0.12 & & -2.50 \\
\hline Sign. Level & & NS & & NS & & NS \\
\hline
\end{tabular}

S-Significant if $P \leq \mathbf{0 . 0 5}, \mathbf{t} \geq \mathbf{1 . 9 6}$ (Significance level=.05) 


\section{H. Testing of level of significance:}

Table IX is showing the increased values of mean of pre and post-merger of Interest Income per Employee (2265109.17 and 6353495.296) Net Profit per Employee (245879.29 and 4269142.402) Business per Employee (35962409.98 and 127399386.4) which has been significantly up in the post merger period consequently the impact of merger is perfectly correlated with the Per employee's performance of SBI. In this table due to non availability of data of 2019 the P-Values of these ratios are greater than 0.05 it shows the impact of the performance over per employee ratios is highly insignificant hence the hypothesis of non significance is accepted notwithstanding it has a correlation with the post merger of SBI.

Table X: Per Branch Ratios

\begin{tabular}{|c|c|c|c|c|c|c|}
\hline & \multicolumn{2}{|r|}{9} & \multicolumn{2}{|c|}{10} & \multicolumn{2}{|c|}{11} \\
\hline & Interest Incom & Branch (Rs.) & Net Profit B & anches (Rs.) & Business/Branch & $s(\mathrm{Rs})$. \\
\hline \multirow[t]{6}{*}{$\begin{array}{l}\text { PRE\&POST } \\
\text { MERGER }\end{array}$} & $\begin{array}{l}2004- \\
2008 \text { (Pre) }\end{array}$ & \begin{tabular}{|l|}
2015 - \\
2019(Post)
\end{tabular} & $\begin{array}{c}2004- \\
2008 \text { (Pre) }\end{array}$ & \begin{tabular}{|l|} 
2015- \\
2019(Post)
\end{tabular} & $2004-2008(\mathrm{Pre})$ & $\begin{array}{l}2015- \\
2019 \text { (Post) }\end{array}$ \\
\hline & $40,677,942.48$ & $93,306,235.35$ & $4,048,168.92$ & $8,021,534.32$ & $532,949,287.58$ & $1,761,354,091.65$ \\
\hline & $41,809,126.04$ & $97,711,092.41$ & $4,701,307.78$ & $5,928,654.49$ & $629,779,040.41$ & $1,903,254,798.38$ \\
\hline & $44,136,769.55$ & $102,223,785.91$ & $4,765,514.87$ & $6,106,058.59$ & $699,432,362.28$ & $2,105,899,694.70$ \\
\hline & $47,441,573.96$ & $98,375,709.65$ & $4,730,528.44$ & $2,921,144.69$ & $812,531,590.83$ & $2,070,680,589.85$ \\
\hline & $55,251,869.33$ & 0.00 & $6,552,214.90$ & 0.00 & $937,632,083.06$ & 0.00 \\
\hline Mean & 45863456.27 & 78323364.66 & 4959546.982 & 3427020.542 & 722464872.8 & 1568237835 \\
\hline STDEV & 5851097.101 & 43898310.13 & 938614.2055 & 4652651.011 & 157675504.7 & 887472416.3 \\
\hline P-VALUE & & 0.213499177 & & 0.547071351 & & 0.131362637 \\
\hline T-VALUE & & -1.48 & & 0.66 & & -1.89 \\
\hline Sign. Level & & NS & & NS & & NS \\
\hline
\end{tabular}

I. Testing of level of significance:

Table $\mathrm{X}$ reflects the increased values of mean while compare to pre and post-merger period of SBI. These changes are: Interest Income per Branch (45863456.27and 78323364.66) Net Profit per Branch (4959546.982and 3427020.542) Business per Branch (722464872.8 and1568237835) which increased the efficiency and productivity after the merger As a result of this it can be conclude that after merger per branch performance will be increasing in future as per the movement of these trend .In this case due to non availability of data of 2019 the P-Values of these ratios are greater than 0.05 it shows the impact of the performance over per branch ratios is highly insignificant hence the hypothesis of non significance is accepted notwithstanding it has a correlation with the post merger of SBI.

Table XI: Key Performance Ratios

\begin{tabular}{|c|c|c|c|c|c|c|c|c|c|c|c|c|}
\hline & \multicolumn{2}{|c|}{12} & \multicolumn{2}{|c|}{13} & \multicolumn{2}{|c|}{14} & \multicolumn{2}{|c|}{15} & \multicolumn{2}{|c|}{16} & \multicolumn{2}{|c|}{17} \\
\hline & \multicolumn{2}{|c|}{\begin{tabular}{|l|} 
Net Profit Margin \\
$(\%)$.
\end{tabular}} & \multicolumn{2}{|c|}{$\begin{array}{l}\text { Operating-Profit } \\
\text { Margin }(\%)\end{array}$} & \multicolumn{2}{|c|}{$\begin{array}{l}\text { Retum on Assets } \\
\text { (\%) }\end{array}$} & \multicolumn{2}{|c|}{\begin{tabular}{|l|} 
Retum on Equity / \\
Net worth (\%)
\end{tabular}} & \multicolumn{2}{|c|}{$\begin{array}{l}\text { Net-Interest } \\
\text { Margin }(X) \\
\end{array}$} & \multicolumn{2}{|c|}{\begin{tabular}{|l|}
$\begin{array}{l}\text { Cost to Income } \\
(\%)\end{array}$ \\
\end{tabular}} \\
\hline \multirow[t]{6}{*}{\begin{tabular}{|c|c|} 
PRE\& \\
POSI \\
MERGRR
\end{tabular}} & \begin{tabular}{|c|}
$20004-$ \\
2008 \\
$(\mathrm{Pre})$
\end{tabular} & \begin{tabular}{|l}
$2015-$ \\
2019 \\
(Post)
\end{tabular} & $\begin{array}{c}2004- \\
2008 \\
\text { (Pre) }\end{array}$ & \begin{tabular}{|c|}
$2015-$ \\
2019 \\
(Post)
\end{tabular} & \begin{tabular}{|c|}
$2004-$ \\
2008 \\
$(\mathrm{Pre})$
\end{tabular} & \begin{tabular}{|c}
$2015-$ \\
2019 \\
(Post)
\end{tabular} & $\begin{array}{c}2004- \\
2008 \\
(\mathrm{Pre}))\end{array}$ & \begin{tabular}{|c}
$2015-$ \\
2019 \\
(Post)
\end{tabular} & \begin{tabular}{|c}
$2004-$ \\
2008 \\
(Pre)
\end{tabular} & \begin{tabular}{|c|}
$2015-$ \\
2019 \\
(Post)
\end{tabular} & \begin{tabular}{|c|}
$\begin{array}{c}2004- \\
2008 \\
\text { (Pre) }\end{array}$ \\
\end{tabular} & \begin{tabular}{|c|}
$2015-$ \\
2019 \\
(Post)
\end{tabular} \\
\hline & 9.95 & 8.59 & \begin{tabular}{|l}
8.33 \\
\end{tabular} & -6.21 & 0.9 & \begin{tabular}{|l|l}
0.63 \\
\end{tabular} & \begin{tabular}{|l|l}
18.19 \\
\end{tabular} & \begin{tabular}{|l|l|}
10.2 \\
\end{tabular} & 4.34 & \begin{tabular}{|l|l|}
2.68 \\
\end{tabular} & \begin{tabular}{|l|l|}
37.07 \\
\end{tabular} & \begin{tabular}{|l|}
36.85 \\
\end{tabular} \\
\hline & \begin{tabular}{|l|l}
11.24 \\
\end{tabular} & 6.06 & 14.04 & \begin{tabular}{|l|}
-10.91 \\
\end{tabular} & 0.93 & 0.42 & 17.88 & 6.89 & 4.3 & \begin{tabular}{|l|l}
.42 \\
\end{tabular} & \begin{tabular}{|l|}
38.75 \\
\end{tabular} & \begin{tabular}{|l|l|}
39.14 \\
\end{tabular} \\
\hline & \begin{tabular}{|l|l}
10.79 \\
\end{tabular} & 5.97 & 14.54 & -14.23 & \begin{tabular}{|c|c|}
0.89 \\
\end{tabular} & 0.38 & 15.94 & 6.69 & 4.18 & \begin{tabular}{|l|l|}
2.28 \\
\end{tabular} & \begin{tabular}{|l|l|}
37.46 \\
\end{tabular} & 41.15 \\
\hline & \begin{tabular}{|l|}
9.97 \\
\end{tabular} & -2.96 & 11.42 & \begin{tabular}{|l|l|} 
\\
\end{tabular} & 0.8 & -0.18 & 14.5 & \begin{tabular}{|l|l} 
& -3.37 \\
\end{tabular} & \begin{tabular}{|l|}
3.9 \\
\end{tabular} & \begin{tabular}{|l|}
2.16 \\
\end{tabular} & \begin{tabular}{|l|l|}
37.66 \\
\end{tabular} & \begin{tabular}{|l|l}
47.52 \\
\end{tabular} \\
\hline & \begin{tabular}{|l|l}
11.85 \\
\end{tabular} & 0.35 & 10.11 & \begin{tabular}{|l|}
-14.14 \\
\end{tabular} & 0.93 & 0.02 & 13.72 & 0.39 & 3.43 & \begin{tabular}{|l|}
2.4 \\
\end{tabular} & \begin{tabular}{|l|}
33.04 \\
\end{tabular} & \begin{tabular}{|l|l|}
44.68 \\
\end{tabular} \\
\hline Mean & \begin{tabular}{|l|}
10.76 \\
\end{tabular} & 3.602 & 11.688 & \begin{tabular}{|l|l}
-13.73 \\
\end{tabular} & \begin{tabular}{|l|l}
0.89 \\
\end{tabular} & 0.254 & 16.046 & 4.16 & 4.03 & \begin{tabular}{|l|}
2.388 \\
\end{tabular} & \begin{tabular}{|l|l}
36.796 \\
\end{tabular} & 41.868 \\
\hline STDEV & \begin{tabular}{|l}
0.821 \\
\end{tabular} & 4.747 & 2.622 & 6.213 & \begin{tabular}{|l}
0.0533 \\
\end{tabular} & 0.327 & 1.985 & 5.505 & 0.376 & \begin{tabular}{|l|l|}
0.193 \\
\end{tabular} & \begin{tabular}{|l|l|}
2.190 \\
\end{tabular} & 4.271 \\
\hline $\begin{array}{l}\text { P. } \\
\text { VALUEE }\end{array}$ & & 0.0304 & & 0.0014 & & 0.0089 & & 0.0024 & & \begin{tabular}{|l|l}
0.0005 \\
\end{tabular} & & 0.1049 \\
\hline $\begin{array}{l}\text { T. } \\
\text { VALUE }\end{array}$ & & 3.281 & & \begin{tabular}{|l}
7.743 \\
\end{tabular} & & 4.746 & & 6.816 & & -34.68 & & -2.089 \\
\hline $\begin{array}{l}\text { Sign } \\
\text { Lemere }\end{array}$ & & s & & $\mathrm{s}$ & & s & & s & & $\mathrm{s}$ & & NS \\
\hline
\end{tabular}

\section{J. Testing of level of significance:}

Table-XI calculated the mean values of pre and post-merger of Net Profit Margin (10.76\% and 3.602\%), mean value of Operating Profit Margin (11.68\% and $-13.736 \%$ ), mean value of Return on assets $(0.89 \%$ and $0.254 \%)$, mean of Return on Net worth $(16.04 \%$ and $4.061 \%)$, mean of net interest margin
(4.03 and 2.388), mean value of cost to income (36.79\%and $41.868 \%)$ respectively. This performs changes in the financial position during the post- merger period except the cost to income. Cost to income has the no significant value $(\mathrm{P}=0.1049)$ in compare to all parameters.Net profit margin, operating profit margin, return on assets, return on equity and net interest margin have lower P-value while we compare with the (0.05) level of significance So it can be concluded only cost to income has no effect while all key ratios lost their performance after merger and accept the significant hypothesis. This is a drawback of merger for SBI financial position.

Table XII: Key Performance Ratios

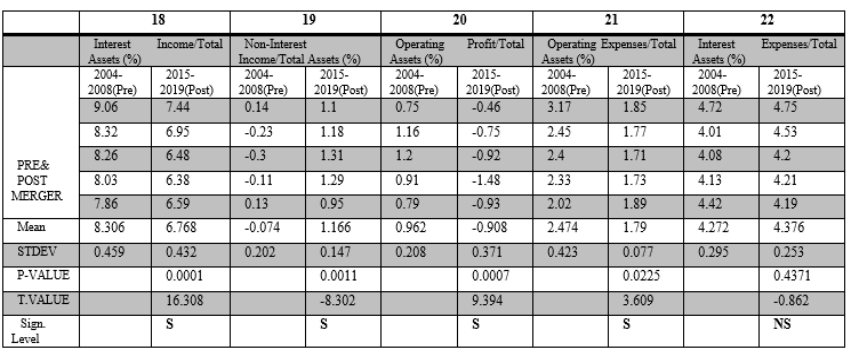

S-Significant if $\mathbf{P} \leq \mathbf{0 . 0 5}, \mathrm{t} \geq \mathbf{1 . 9 6}$ (Significance level=.05)

K. Testing of level of significance: Table XII calculate the mean values of pre and post-merger for Interest Income/Total Assets $(8.306 \%$ and $6.786 \%)$, mean value of Non-Interest Income/Total Assets $(-0.074 \%$ and $1.166 \%)$, mean value of Operating Profit/Total Assets ( $0.962 \%$ and $-0.908 \%)$, mean value of Operating Expenses/Total Assets (\%) $(2.474 \%$ and $1.79 \%)$, mean value of Interest Expenses/Total Assets (4.272 and 4.376), while $P$ values of pre and post-merger of SBI are $0.001,0.0011,0.007,0.0225 \& 0.4371$ respectively(Interest

Income/Total Assets , Non-Interest Income/Total Assets (Operating Profit/Total Assets, Operating Expenses/Total Assets ,Interest Expenses/Total Assets ) Hence the only value of non interest expenses has no significant difference after the merger while Interest Income/Total Assets has decreased, Non-Interest Income has been increased /Total Assets Operating Profit/Total Assets come down heavily and Operating Expenses/Total Assets decreased after the merger. The null hypothesis is accepted only in case of interest expenses/Total Assets.

Table XIII: Valuation Ratios

\begin{tabular}{|c|c|c|c|c|c|c|c|c|c|c|c|c|}
\hline & & & \multicolumn{2}{|c|}{24} & \multicolumn{2}{|c|}{25} & \multicolumn{2}{|r|}{26} & \multicolumn{2}{|c|}{27} & \multicolumn{2}{|c|}{28} \\
\hline & \multicolumn{2}{|c|}{ Enterprise Value (Rs. Cr) } & \multicolumn{2}{|c|}{$\begin{array}{ll}\begin{array}{c}\text { EV } \\
\text { Sales }(X)\end{array} & \text { Per } \\
\text { Net }\end{array}$} & \multicolumn{2}{|c|}{$\begin{array}{l}\text { Price to Book } \\
\text { Value }(X) \text { (X) }\end{array}$} & \multicolumn{2}{|c|}{ Price to Sales $(X)$} & \multicolumn{2}{|c|}{ Retention Ratios (\%) } & \multicolumn{2}{|c|}{$\begin{array}{ll}\text { Earnings } & \text { Yield } \\
(\mathrm{X})\end{array}$} \\
\hline \multirow{6}{*}{\begin{tabular}{|c|c|} 
PREs \\
POST \\
IIIRGER
\end{tabular}} & 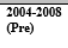 & $\begin{array}{l}2015-2019 \\
\text { (Post) }\end{array}$ & $\begin{array}{c}2004 \\
2000 \\
\text { (Pre) }\end{array}$ & 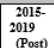 & $\begin{array}{c}2004- \\
2008 \\
\text { (re) }\end{array}$ & \begin{tabular}{|c|c|c|}
$2015-$ \\
2019 \\
(1)
\end{tabular} & $\begin{array}{c}2004- \\
2008 \\
\text { (2) }\end{array}$ & $\begin{array}{c}2015- \\
2019 \\
\text { (Post) }\end{array}$ & \begin{tabular}{|c|}
$2004-$ \\
2008 \\
$($ Pre)
\end{tabular} & \begin{tabular}{|c|}
$2015-$ \\
2019 \\
(Post)
\end{tabular} & $\begin{array}{c}2004- \\
2008 \\
\text { (Pre) }\end{array}$ & \begin{tabular}{|c|c|}
$2015-$ \\
$2019-$ \\
(Posto
\end{tabular} \\
\hline & $344,886.65$ & $1,865,394.71$ & 9.32 & \begin{tabular}{|l|l|}
12.24 \\
\end{tabular} & $\begin{array}{l}1.58 \\
\end{array}$ & \begin{tabular}{|l|}
1.55 \\
\end{tabular} & $\begin{array}{ll}0.86 \\
\end{array}$ & 1.31 & \begin{tabular}{|l|}
84.27 \\
\end{tabular} & \begin{tabular}{|l|}
79.78 \\
\end{tabular} & 0.12 & 0.07 \\
\hline & $403,996.72$ & $2,075,268.45$ & 10.55 & 12.65 & \begin{tabular}{|l}
1.44 \\
\end{tabular} & 1.05 & 0.9 & 0.92 & 84.71 & 79.71 & 0.12 & 0.07 \\
\hline & $439,982.96$ & $2,467,752.16$ & 10.78 & 14.06 & \begin{tabular}{|l}
1.84 \\
\end{tabular} & 1.49 & 1.25 & 1.33 & 83.27 & 79.88 & 0.09 & 0.04 \\
\hline & $498,404.22$ & $3,141,292.12$ & 10.94 & \begin{tabular}{|l|l|}
14.25 \\
\end{tabular} & \begin{tabular}{|l|}
1.67 \\
\end{tabular} & 1.15 & 1.15 & 1.01 & 83.77 & 100 & 0.09 & -0.03 \\
\hline & $638,559.38$ & $3,423,771.88$ & 11.25 & \begin{tabular}{|l|}
14.1 \\
\end{tabular} & 2.06 & 1.3 & 1.78 & 1.18 & 79.82 & 100 & 0.07 & $v$ \\
\hline \begin{tabular}{|l|} 
Mean \\
\end{tabular} & 465165.986 & 28946998.864 & 10.56 & \begin{tabular}{|l|}
13.46 \\
\end{tabular} & \begin{tabular}{|l}
1.718 \\
\end{tabular} & 1.308 & \begin{tabular}{|l}
1.188 \\
\end{tabular} & 1.15 & 83.168 & \begin{tabular}{|l|}
87.874 \\
\end{tabular} & 0.098 & 0.03 \\
\hline \begin{tabular}{|l} 
STDEV \\
\end{tabular} & 111817.968 & 671533.092 & 0.742 & 0.940 & \begin{tabular}{|l}
0.240 \\
\end{tabular} & 0.214 & 0.369 & 0.181 & \begin{tabular}{|l|}
1.947 \\
\end{tabular} & \begin{tabular}{|l}
11.069 \\
\end{tabular} & 0.021 & 0.044 \\
\hline \begin{tabular}{|l|l} 
P- \\
VAAUE
\end{tabular} & & 0.0010 & & \begin{tabular}{|l|l|}
0.001 \\
\end{tabular} & & 0.026 & & 0.834 & & 0.444 & & 0.007 \\
\hline \begin{tabular}{|l|} 
TILUE \\
VALUE \\
\end{tabular} & & -8.40 & & -13.23 & & 3.447 & & 0.223 & & -0.848 & & 5.013 \\
\hline \begin{tabular}{|l|} 
Sign. \\
Level \\
\end{tabular} & & $\mathrm{s}$ & & $\mathrm{s}$ & & $\mathrm{s}$ & & NS & & NS & & 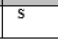 \\
\hline
\end{tabular}

Published By: 


\section{Pre-Merger and Post-Merger Operating Performance of SBI}

L. Testing of level of significance: Above analysis (see table XIII) reveals the (S-Significant if $\mathbf{P} \leq \mathbf{0 . 0 5}, \mathbf{t} \geq \mathbf{1 . 9 6}$ Significance level=.05)P values of pre and post-merger of Enterprise Value, EV/ Net Sales, Price to book value and earning yield are highly significant which are $(0.0010,0.0001$, 0.0261 and 0.0007 ) less than 0.05 that is significant level so null hypothesis is rejected while Price to sales and retention ratio are having no significant with the pre merger and post merger because these parameters have higher $\mathrm{P}$ values in compare to hypothesis level. The conclusion of above analysis is that after merger of SBI associates into SBI the market value has been increased but the price to sale and retention ratio accepts the null hypothesis.

\section{FINDINGS AND CONCLUSION}

The State Bank of India announce the result for March 2018 it faces a loss of Rs.7, 718 crore when we traced back the reason, find out the bad loan of SBI goes up by $12.2 \%$ because of the Merger of all associates later on the SBI revive itself and reduces the cost of operation to fill the gap of this loss and finally till 2019 came out of this crisis by achieving the profit of Rs 838.40 crore. The main findings of this study are; the earning of the shareholders has been reduced but the value of the firms goes up after the merger of all associates. It is clear from the analysis during 2008 the merger of SBS gives a remarkable growth and its presence in Saurastra to SBI later on SBI continue this consolidation and reduces the all operating expenses by $2.34 \%$.With this biggest merger SBI has displayed its capabilities to be a leader in Indian Banking Industry. It has been proved by this research the merger reduces the cost of banking operation for long terms perspective. After the first two merger of SBI the price per ratio, key performance ratio and valuation ratio goes up and enhance the productivity and profitability of the Bank while in case of the merger of five associates and Bhartiya Mahila Bank the financial performance of SBI come down heavily because of their sickness it increase the burden to the bank as well as shareholders then SBI manage any how to block up this gap by increasing retention ratio, nonetheless after two years of merger SBI got successful to achieve higher market value and profitability as few years ago of merger. However the results would be clearer in upcoming years. It is concluded that after merger somehow the overall financial performance of the bank has been improved but this change is not good enough to be a benchmark until the SBI would not recover the bad loan otherwise the SBI will remain in the losses as long as it does not minimize operating cost. The aim of financial inclusion and enlargement of geographical access of banking services by synergizing can be achieved better with the merger of large public sector banks and leveraging on their expertise.

\section{REFERENCES:}

1. Ataullah A, Cockeri.T, Le H (2004). "Financial Liberalization and Bank Efficiency: A Comparative Analysis of India and Pakistan". Appl. Econ. 36(17):1915-1924.

2. Antony Akhil, K. (2011), "Post-Merger Profitability of Selected Banks in India," International Journal of Research in Commerce, Economics and Management, Vol. 1, No. 8, (December), pp. 133-5.

3. Ashutosh, Dash (2005), "The post - merger performance Puzzle: An evaluation of long - term profitability of Indian firms ", The ICFAI Journal of Accounting Research, January 2015, pp.no. 6-22.

4. Atma, Prasantha (1996), "Performance of Public Sector Commercial Banks - A Case Study of State Bank of Hyderabad", PhD Thesis, Osmania University, Hyderabad, pp.no. 1-308.

5. Bhatnagar Baxi Abhinn \&Sinha Nitu (2012), "Strategic Move of ICICI Bank: A Case of ICICI Bank \& Bank of Rajasthan”, International Journal of Multidisciplinary Research Vol.II, No. V. pp.no. 9-15.

6. Chanda, Kumar Dalip (2005), "Bank Mergers in India: A critical Analysis”, IASSI Quarterly, Vol. XXIII, No. IV, pp.no. 107-123.

7. Chen T-Y (2004) A study of cost efficiency and privatization in Taiwan's banks: the impact of the Asian Financial Crisis" Ser. Ind. J. 24(5):137-151.

8. Cornett, Marcia. Millon, and Tehranian, Hassan (1992), "Changes in corporate performance associated with bank acquisition, Journal of Financial Economics, Vol.XXXI, pp.no. 211.234.

9. Dimikris angelids and Katerina lyroudi (2006) Efficiency in the Italian Banking Industry DEA and neural networks", "International research journal of finance and economics", Vol.1, Issue 5, 2006. pp. 155-165

10. Ghosh, A., (2001): 'Does operating performance really improve following corporate acquisitions?' Journal of Corporate Finance 7 pp 151-178.

11. Khan, Azeem Ahmad (2011), "Merger and Acquisitions (M \& As)" in the Indian banking sector in post liberalization regime", International journal of contemporary business studies, Vol.II, No. XI, November, pp.no. 31-45.

12. Khurana B. (2017). "ANALYSIS OF MERGER OF SBI \& ITS ASSOCIATES.” International Journal of Research - Granthaalayah, 5(5), 391-393

13. Kumar, Ashwani and Kishore, Deep (2003), "An Assessment of Banking Sector Reforms in India”, Indian Journal of Public Enterprise, June, pp.no. 87-101.

14. Kumar, R., 2009. "Post-Merger Corporate Performance: an Indian Perspective", Management Research News 32 (2), pp. 145-157.

15. Mantravadi, P. and A. Reddy, (2008). "Relative Size in Mergers and Operating Performance: Indian Experience", Working Paper Series, available at: www.ssrn.com (accessed March 15,2008)

16. Monika (2014), "Mergers and Acquisitions in Indian Banking SectorA Comparative Study on Pre-post-Merger", International Journal of Economic and Management Strategy, Vol.IV, No.I, pp.no. 1-14

17. Nedunchezhin, K Premalatha (2011);"Analysis of pre and post merger public sector bank efficiency: A DEA analysis”, International Journal of Applied Research and Studies, Volume 3, Issue 1(Jan 2014), pp.1-12

18. Seetharaman, A, Lee, N.G.Shir and Raju, Sudha (2007), "The Impact of the merger of Malaysian Bank", Finance India Indian Institute of Finance, Vol. XXII.No. IV, December, pp.no. 1309-36.

19. Santos José O. Dacanay III, (2007), "Malmquist index and technical efficiency of Philippine Commercial banks in the post-Asian financial crisis period", "Philippine Management Review 2007", Vol. 14, pp 93-114.

20. S.R. Singh and V. Kumar, (1994). Corporate Rehabilitation and BIFR (New Delhi Shipra Publications, pp. 67.

21. 21. Vanitha, S. and M. Selvam, 2007. Financial Performance of Indian Manufacturing Companies during Pre and Post Merger. International Research Journal of Finance and Economics, 12:7-35

22. www.moneycontrol.com

23. www.sbi.co.in

\section{AUTHORS PROFILE}

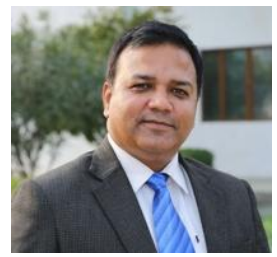

Dr. Anshul Sharma is a man of Finance having more than 15 years experience of P.G. teaching with institution of high repute and 4 years' experience of Banking. He is working as Head of the Department of Management. He has a rich experience of administration in varied capacities including Dean, Director, Procter, Chief Editor, Centre Superintendent, Examination Controller, Research Guide, Paper Setter, Placement Coordinator and Head - Cultural Activities and has been Member of Academic Council, Executive Council, Faculty Board and Board of Studies in different Universities. 
Along with good administrative experience he has a rich experience of research guidance and publications and is associated with different journals as Member of Editorial Team and Reviewer. He has conducted Workshops and attended number of Seminars, Workshops and FDP's as a Resource Person. He has around 20 international and 5 national publications in various journals.

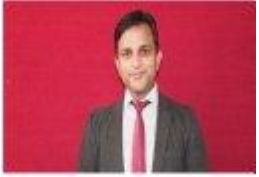

FarmanAli, he is Assistant Professor at MBA department at Uttaranchal University, Dehradun. He is UGC-NET qualified and he is pursuing his $\mathrm{PhD}$. 